\title{
WATERFRONT DEVELOPMENT STRATEGY OF THE OLD KALIMAS PORT BASED ON THE ZONING OF TANJUNG PERAK PORT
}

\author{
Rabbani Kharismawan*, Adi Nugroho Ngestitomo* \\ *) Department of Architecture, Institute of Technology Sepuluh Nopember, \\ Indonesia \\ e-mail: rabbani@arch.its.ac.id
}

\begin{abstract}
Waterfront area is a special place in major cities around the world. Place to work, play or fulfilling a sense of curiosity. The old Kalimas Port is also no exception. As well as waterfront areas in other major cities, as a place for change (transition), with so many maritime facilities and a few new activities to attract people to the waterfront. When future generations are look back on this transition as historical moment of Kalimas River, they who are live today would feel that too many waterfront areas are separated from the public for a long time. The challenge of the waterfront development area is not only to help change the Kalimas riverfront as far as $2.5 \mathrm{~km}$, to be a place to reflect modern traditions and a sense of place, but also take into account the history as an important role.

By using a qualitative and descriptive method, the study aims to make a comparative analysis from some of the successful waterfront development concepts with the same character of the region, the old industrial riverfront area.

The results are the waterfront development strategy, particularly in the Old Kalimas Port which is also part of the Tanjung Perak Port in Surabaya. It requires some special criteria, the vision and missions of the waterfront planning and development concepts. While in the old Port development strategy, in terms of the physical condition of the area and the Port authority policies, formulate zoning strategies as a macro strategy in the future sustainability of the region. The zoning strategy develop three micro zones; the old Port zone, recreational zone and commercial zone. The three zones have their own strategies which will be mutually support the sustainability of economic, social and cultural sector.
\end{abstract}

Keywords: Old Kalimas Port, Tanjung Perak Port, Waterfront Development 


\section{INTRODUCTION}

Excerpts from the book Waterfront in Post-Industrial Cities; "The success of a city will not be achieved if the physical environment of the city is ignored. When the role of the city shifts from industry to economic support, the main thing of its success is the quality of the city space, where the waterfront has a big role. "

The first reason; in general, the waterfront is the worst place in the city, due to its former industrial location. Second, because the waterfront is the most visible (public attention) location in most cities. For this reason, the development of a waterfront is very important for the development of the city and also the quality of the city's environment.

The waterfront area of a big city is a special place. A place to work, have fun or fulfill curiosity. The Old Kalimas Port is also no exception. As is the case with waterfront areas in other large cities, as a place of change (transition), with so many maritime facilities and very few new activities that can draw people's attention to the water's edge. When future generations will see this transition again as the historic moment of the Kalimas River (Figure 1 and 2), those who live today will feel that there have been too many waterfront areas separated from the public for a long time. The challenge of the process of developing a waterfront area is to help change the Kalimas Riverfront as far as $2.5 \mathrm{~km}$ into a place that can reflect modern traditions and place sensitivity, but also take into account the history as an important role.

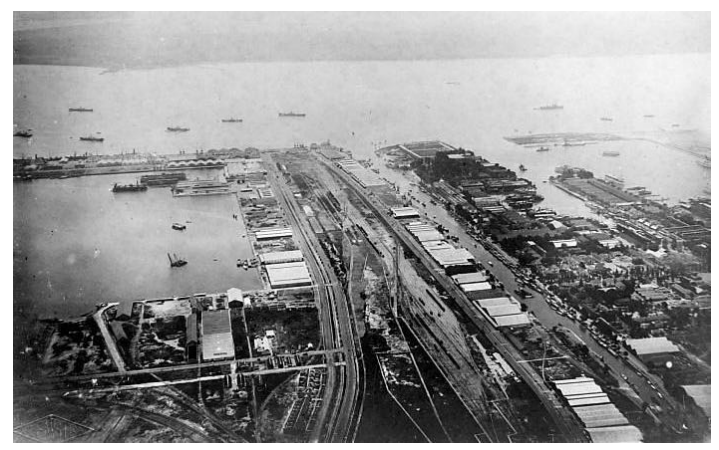

Figure 1. The Port of Tanjung Perak Harbor formerly called Oedjoeng Harbor Source: Collection of Tropen Museum

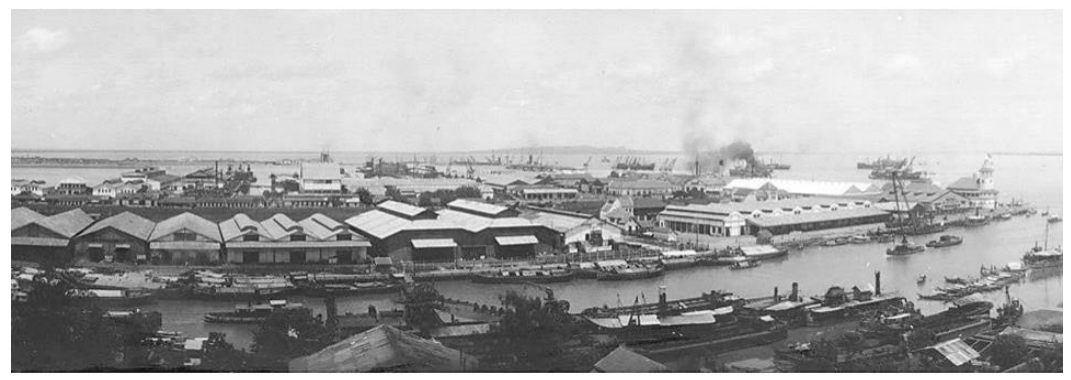

Figure 2. Panorama of The Port of Tanjung Perak, circa 1915, viewed from the east side Source: Collection of KITLV 
In some meetings with the Indonesia Port Corporations, there were questions regarding the visions on eastern Port and Kalimas Riverfront. Some wish to present the glory of old industrial and maritime trade in Tanjung Perak. And the other, see it as a place for recreation and vital business activity along the riverbanks, a place to enjoy food and beverages, work, rent a bike, launched a small boat, or enjoy the breeze and take shelter from the scorching sun. And the rest were hoping it will be a nice place to take a break, enjoy nature and beautiful beaches.

In the planning process, ideas or concepts will emerge that bridge the big goal of the Tanjung Perak Harbor to unite the city with its riverbanks. These concepts are recorded in the waterfront development mission and the concepts will be reflected in all land-use policies. These missions are intended so that in the implementation of this development, it will remain a reference for achieving the type and balance of waterfront activities that will unite the city of Surabaya with its riverbanks.

Surabaya, a city designed by the Dutch in the Colonial era also has a waterfront as a water transportation route. Surabaya then developed as an industrial city and the second largest after Jakarta. But along with the times, the quality of the river and the environmental quality of the riverbanks began to decline. The same thing happened in Singapore, but in the 70-80s, based on the Prime Minister's vision, the quality of the river and the riverbank environment in Singapore became an icon (attraction) for tourists while enhancing Singapore's image.

The research area is in the Pabean Cantikan district and is the Port of Tanjung Perak area, Surabaya (Figure 3). The research area is along the West side of the Kalimas River starting from the Petekan Bridge to the Ujung Tanjung Perak crossing. The boundaries of the research area are as follows:

1. East: Kalimas River, Armatim TNI AL

2. West: Jalan Kalimas Baru

3. North side: Ujung Tanjung Perak Crossing Pier

4. South: Jalan Sisingamangaraja Baru, Petekan Bridge

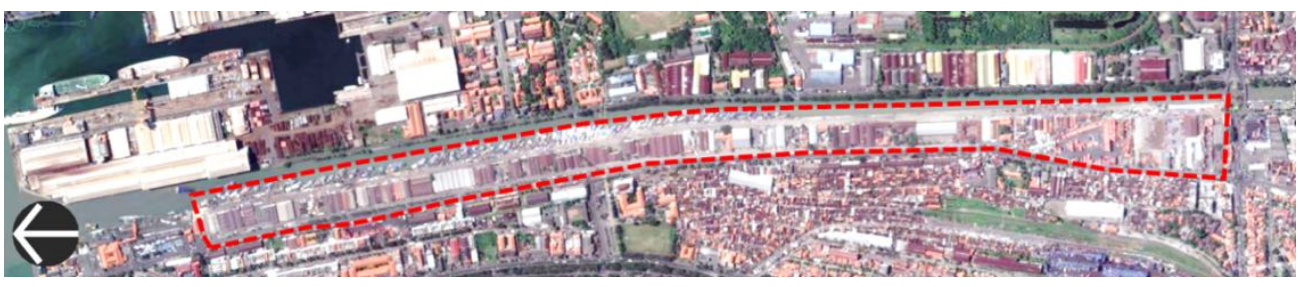

Figure 3. The Old Kalimas Port's research perimeter

\section{Building Intensity Regulation}

The building intensity in the study area includes the Building Coverage Ratio (KDB), Building Setbacks (GSB) and Floor Area Ratio (KLB). The KDB in several places varies, from $5 \%$ to $100 \%$. KDB $5 \%$ to $10 \%$ is on land that functions as container depots and Port areas, where the proportion of buildings on container depots is very small because the majority are used as container's site. Whereas the area with $\mathrm{KDB}$ between $15-60 \%$ is in the land which is used as a drinking water 
treatment plant, ex-Petekan Market and offices. While areas with KDB above $60 \%$ are in areas with warehousing and showroom functions, where all available land is used as buildings.

Building Setbacks (GSB) in the study area is 1-4 meters, especially buildings along the road in the Kalimas Port. While buildings that do not have setbacks are the number of buildings in the jetty area. For buildings that are on the Kalimas road have a GSB of approximately 2-10 meters.

For Floor Area Ratio (KLB) in the study area, the average is a one-story building, but some buildings have a height of 2-3 floors, i.e. the office building.

\section{Outdoor Space Functions and Conditions}

The outdoor function in the research area is divided into three:

1. Outdoor Space

This outdoor space is an access road inside and outside the area that connects one region to another. This space functions as a space for transportation of motorized vehicles and non-motorized vehicles.

2. Space between buildings

Outer space between buildings is the space formed by the separation between buildings or around buildings, for example, parks, alleys, private parking.

3. Public outdoor space

Public spaces are outdoor spaces that can be accessed by anyone such as parking, parks, walkways and so on.

In addition to the environmental conditions inside the area, there are also existing environmental conditions around the study area. Environmental conditions around the area consist of several functions and activities, which are offices, warehousing, Navy Base (Armatim), PT.PAL, hospitals, ferry docks, gas stations and other functions (Figures 4 and 5).

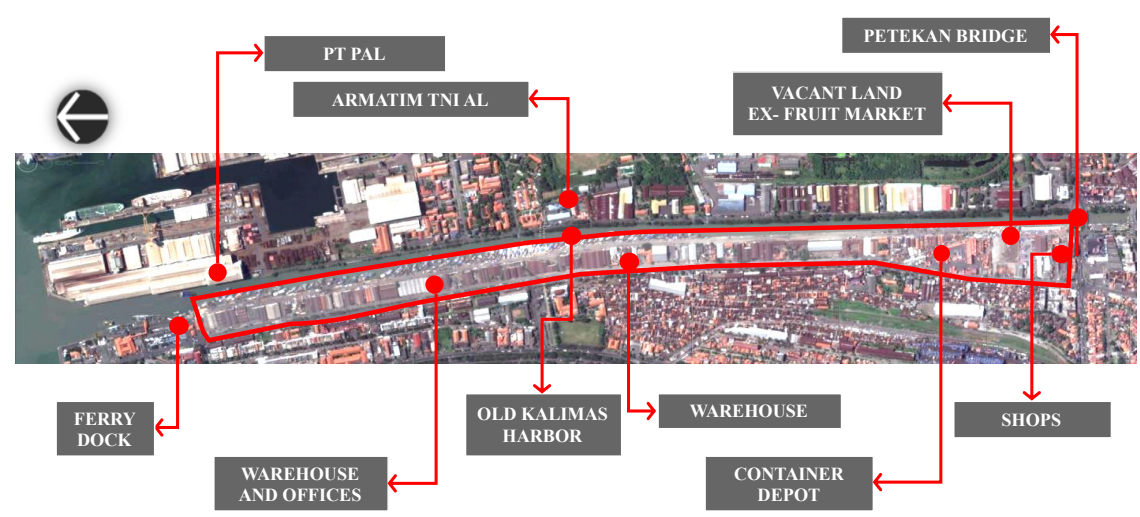

Figure 4. The land use existing condition Source: Collection of Tropen Museum 


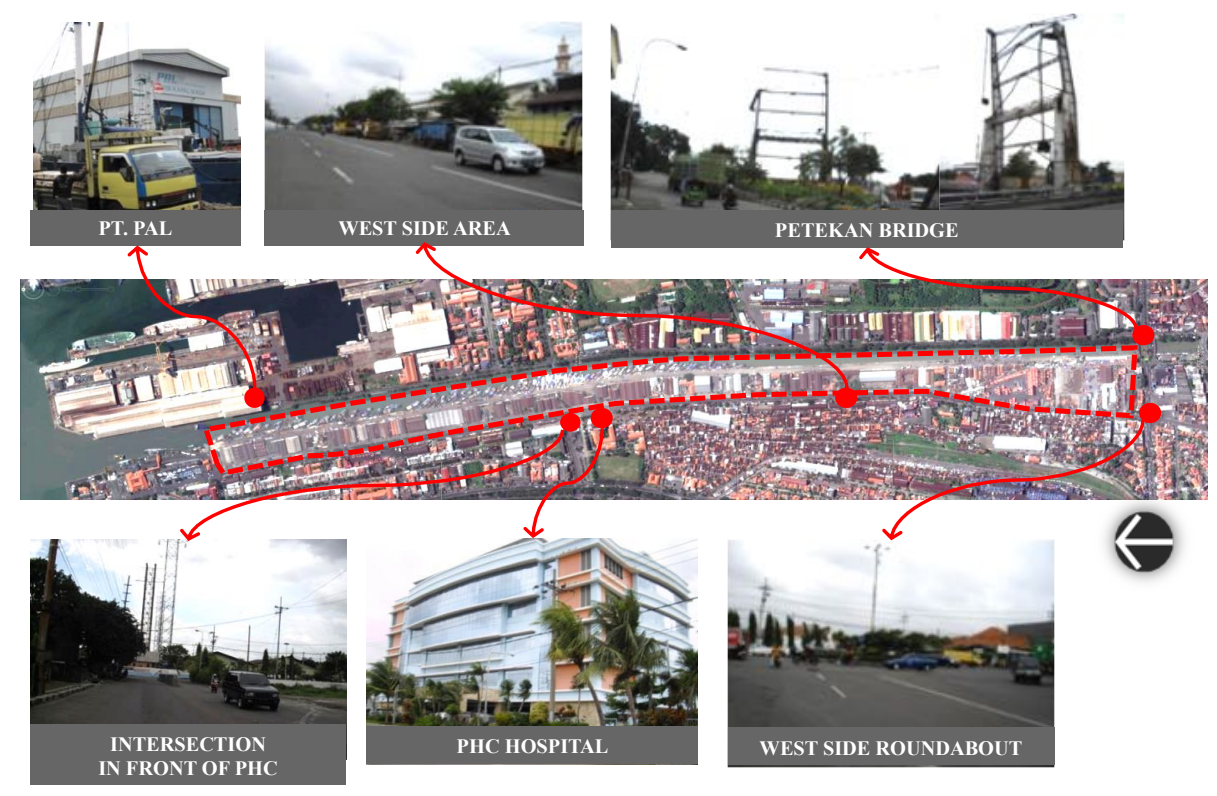

Figure 5. The urban structure around the Old Kalimas Port proximity Source: Collection of Tropen Museum

\section{THEORY / RESEARCH METHODS}

This research is a descriptive study. Descriptive research tries to discuss the real problems of the Old Kalimas Port in the Port of Tanjung Perak, Surabaya. A descriptive method designed to gather information about the current (real-time) reallife situation.

Because there is no research on the transition of the function of the port into a tourism function or public space that is integrated with the zoning of the main port area. So research is needed that also compares the waterfront area in Surabaya and abroad both in terms of physical, non-physical and policy.

To get detailed data, data collection is done by observing all locations through data collection, taking photos, and measuring the basis, if needed. From the results of these primary and secondary survey, data will be processed with comparative analysis and optimal suitability for land use in the Old Kalimas Port.

The analytical method being used was a descriptive qualitative method to make a description of the tendency of the conditions of each variable, as well as using a comparative approach to the concept and the establish conditions from overseas waterfront arrangement. The sequence can be described as follows:

a) Investigation and analysis of land use types, building mass types and intensities, and locations.

b) Descriptive analysis techniques to describe the character of the Old Kalimas Port area.

c) Descriptive-qualitative analysis techniques to analyze the condition and physical structure of the Old Kalimas Port 
d) Comparative analysis between the physical condition of the Old Kalimas Port all areas and the physical condition of the waterfront area built overseas.

\section{RESULTS AND DISCUSSION}

\section{Development Concept}

To formulate a development strategy, several formulations were first made that refer to the literature review and case studies for the development of waterfront areas. Some of these formulations include:

a. Explain the Vision and Mission of the Old Kalimas Port Waterfront Area

b. Explain the Concept of Planning and Development, referring to the policy of PT. Pelindo III.

\section{Vision and Mission of the Future Old Kalimas Port}

In every waterfront area development that is carried out overseas, a statement which is often called a vision is needed, which is agreed by all stakeholders regarding the Vision that underlies the idea of setting up and developing the Kalimas Port, Tanjung Perak Port Surabaya:

"Reuniting the city of Surabaya with its riverbanks by developing the land of PT. Pelabuhan Indonesia (Pelindo) III, the branch of Surabaya's Tanjung Perak, as a riverside city park that combines historic activities (old Port) and culture (city parks) with the provision of facilities and activities for tourists and the general public ".

The concept of providing facilities considered is as follows: promenade or pedestrian path, entertainment area and shopping center; family recreation area and children's playground. Tourism spot and facilities to go along the river.

To achieve this goal (vision), the development of the Kalimas Port, Tanjung Perak Port, Surabaya can be implemented in several targets (missions) as follows:

\section{Waterfront as a place of work}

"The Old Port must continue to serve current and future needs such as cargo shipping, boat recreation and all activities that depend on water."

The Old Port has a great maritime historical value. Reinforced by the existence of Syahbandar. The existence of the Port must continue to serve current and future needs for activities that depend on water, namely activities that require access to the waterfront as basic needs. In order to meet the needs of activities that depend on water, waterfront land use plans are intended to:

a.Continuity of cargo shipping and receiving operations in the waterfront area.

b. Develop the potential for recreational boats and water activities along the waterfront. 
c.Develop water taxis in several parts of the waterfront as a transportation option.

This maritime historical value has become an attraction, not only for inter-island trade, but also tourist attractions. This is due to a similar scene that has lasted for decades since the colonial era, which was marked by the arrival of traditional ships (Pinisi sailing ship) from outside Java, such as Kalimantan, Sulawesi and even Sumatra.

\section{Port Development}

"Later, new investment will encourage the development of waterfronts, opening jobs, income, improving public facilities and other benefits to the Port of Tanjung Perak, the city of Surabaya and the Indonesian State."

Many port and waterfront activities that require an increase in capital are far greater than the capabilities that can be borne alone. If an increase in capital and the provision of public facilities (such as open space and pedestrian pathways) will require financing, a better balance between subsidized financing and activities that produce income must be achieved.

The Kalimas Port development plan identifies new investment potential in the form of mixed-use development, which will provide capital for re-investment in maritime and port facilities, public lanes and park procurement, and public gathering places.

Private capital can be included, if consensus (agreement) has been reached in the planning. This is to obtain certainty that initial capital is indeed needed and for revitalization. This revitalization area will enhance and complement the exciting new environment that has existed at the port for years.

The rise of the waterfront will restore financial strength to the Kalimas Port, encourage employment and tax revenue growth for the city, and open up many business opportunities.

\section{Diversity of Activities and People}

"The waterfront area and harbour must be able to accommodate a variety of interesting activities from the maritime, commercial, entertainment, public, open space, recreation and waterfront activities for Surabaya residents and visitors."

With the realization of this waterfront facility, it is expected to attract the interest of many people to visit, work and enjoy the beauty and attraction of waterfront objects. The east side Port of Tanjung Perak, which stretches for \pm 2.5 kilometers from north to south, to the Petekan Bridge, offers the potential to be able 
to accommodate the diversity of maritime and non-maritime activities as is happening now (2012).

With the opening of the port development plan, activities that depend on water will be interspersed with other land uses to increase public interest in riverbanks. A network of mixed-use activities should arise along the waterfront, and reflect diverse ethnic cultures and lifestyles, and the interests of seamen, employees and local residents, parents and young people, those with special needs, recreational lovers and those seeking peace.

The port, in its implementation of the waterfront land use plan, must be able to encourage and balance the waterfront use and activities. Various types of open space, recreation, new maritime and commercial activities, all must be accommodated at the port, will re-destabilize the city with its riverside (waterfront) by providing a gathering place, full of activity, which is safe during the day and night.

\section{Access to and along the Riverfront}

The network of parks, open spaces, pedestrian paths, open spaces and improved transportation facilities must increase access to, and interest in and appreciation of the Kalimas River environment.

Improvement of transportation routes, improvement of public stops, and pedestrian promenades will result in historical changes to the waterfront, creating public access and good and connected public stops along the perimeter of the planning site.

Park areas, open spaces and plazas, as well as areas for nature, habitat and environmental improvement, must provide outdoor spaces where all public segments can enjoy waterfront activities or access to public port tours at certain times. The viewport and information board must provide visual access to waterfront activities where vehicle access is restricted.

Planning encourages improved access that will allow anyone to enjoy the cultural, natural and environmental diversity of cultural heritage by:

a. Creating a pedestrian pathway that connects several new open spaces and interesting port activities.

b. Provide a public view area and a sign that explains the choice of waterfront activities, such as cargo loading and unloading and other public facilities.

c. Creating the "Historical Trail of the Old Kalimas Port" as part of increasing public access in efforts to preserve the history of the port of Tanjung Perak, to provide public access to parts of the port that have been closed. Providing views of past warehousing with mooring traditional cargo ships that are still operating. 
d. Encouraging jetties or boat moorings for recreation and other water transport enhancements in relation to recreational and commercial functions.

e. Arranging truck routes and public roads and transporting goods to serve the cargo shipping industry.

f. Provision of public facilities such as restrooms, drinking water, food and beverage vendors, and bicycle rental if possible

g. Supports transportation access for all users, including several transit points.

\section{The Evolving Waterfront, Referring to the Past and the Future}

Development must respect and enhance the historical character of the waterfront, while also creating new opportunities for city residents to incorporate port activities in their daily lives.

The evolution of the riverbank (waterfront) from the beginning until now reflects the rich value of the historical value of the city of Surabaya. Waterfront must continue as a store of past memory, as well as provide new possibilities. Realizing that waterfronts will continue to develop, a balance must be maintained between the sustainability of maritime activities, expanding public activities, protecting the architectural character and historical value of waterfronts, opportunities for nature and habitats to protect and survive, and financial responsibility.

There will be additional changes to the waterfront infrastructure (for example the change of the loading and unloading lanes to the promenade along the east side of the waterfront) to the mixed use development function, and must be responsive to the city's maritime historical value, and must ensure several buildings and sections of waterfront cultural heritage, identified in This urban design guide plan, will be maintained in the process of its development, wherever it is.

\section{The Planning Concepts and Developments}

The development concept proposed in the Old Kalimas Port area is the planning and development of the Kalimas loading and unloading which has historical cultural values as a Commercial, Recreational, Educational and Cultural Business area (Figure 6).

\section{A. Concepts of Functions}

The concept of the function of activities in accordance with the development area is as follows:

1. Business and Trade Areas

2. Recreation / tourist areas, education and culture. 
The function of Trade Business activities related to the existing function of the area as people's ports, warehousing and offices is maintained while at the same time restructuring and overall development are carried out.

The function of Trade Business Activities is contained with 2 (two) concept activities:

1. The concept of maritime business and trade that is the port of the people and their offices / warehouses.

2. The concept of modern business and trade is offices, shopping centers, hotels and apartments that are integrated into one block.

Functions of Recreation / Tourism Activities, Education and culture in the planning area of the Marina Tourism concept, where recreational activities, sports, games, nature, water, food are oriented to rivers and water.

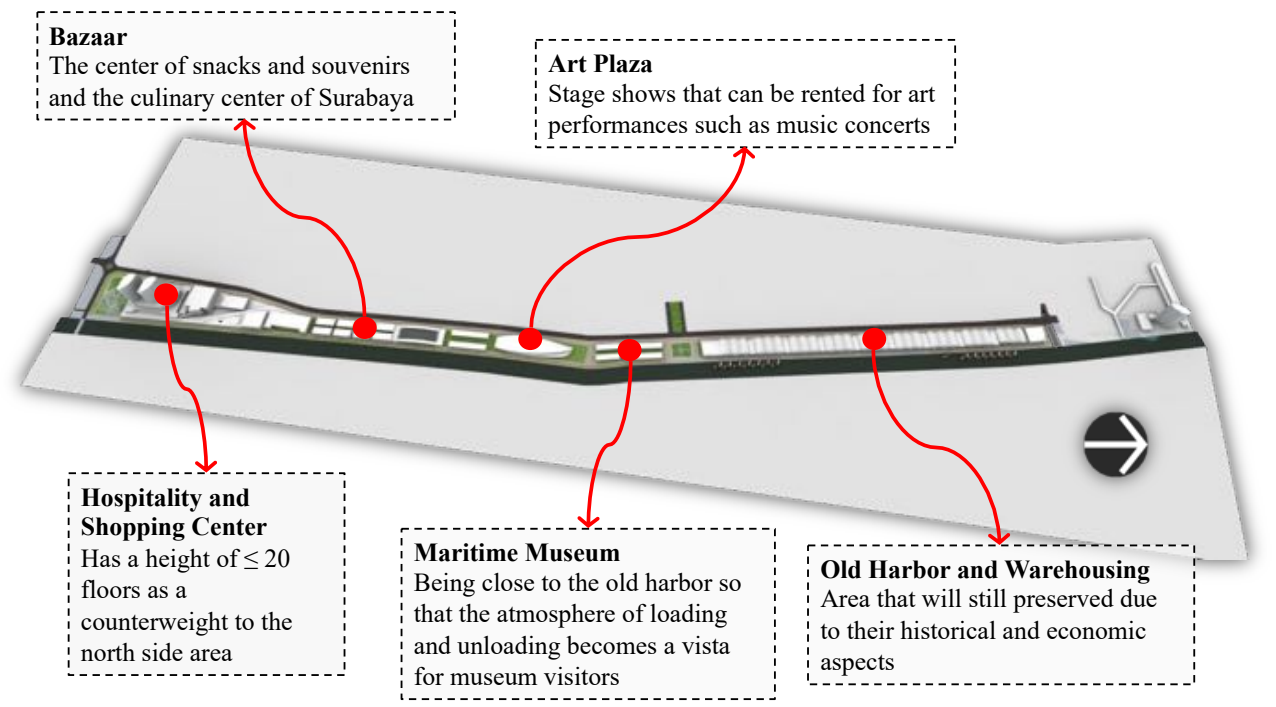

Figure 6. The New “Old Port” Development Strategy

\section{B. Concepts of Zoning and Blockplan}

The concept of Zoning in the Development Zone is divided according to the type and function of its activities, that is the trade business area and the Recreation / Tourism area (Figure 7).

There are 2 (two) types of trade business zones, that is trade business zones in the Kalimas port area and modern trade business zones in the south of the region. In the trade business zone in the port area is divided into several concept blocks in accordance with its scope, especially the function of activities:

1. Old Kalimas Port

2. Warehousing

3. Offices and shops 
4. Parking zone and open storage

5. And circulation

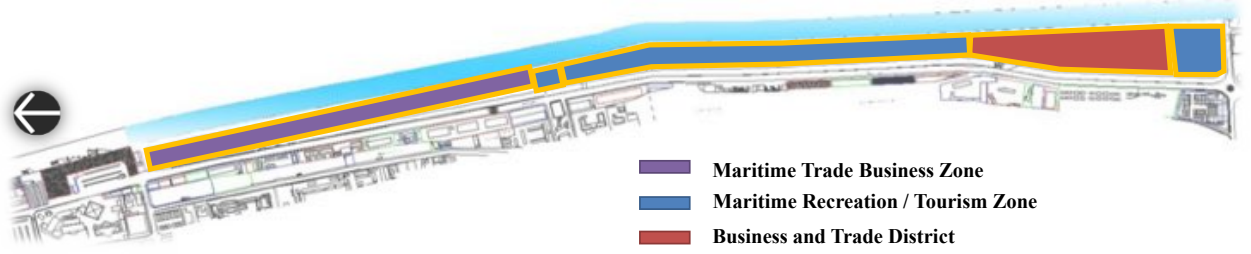

Figure 7. The New "Old Port" Zoning Concept

Whereas the recreation / tourism zone is also divided into several block concepts according to the extent and activities of the activities, i.e. (Figure 8):

1. Commercial tourism / recreation block
a. The attraction games
b. Food stall building
c. Souvenir stall building
d. Multifunction Hall
e. Riverfront promenade
f. Sidewalk / pedestrian
g. Parks and urban forests
h. Manager
i. Public facilities

2. Non-commercial public tourism / recreation block
a. Playground facilities
b. Sports facilities
c. Outdoor gym
d. Outbound area
e. water park
f. Amphitheater
g. Parks and urban forests
h. Take away kiosk

3. Tourism / cultural tourism / recreation block
a. Museum
b. Tower of view

4. Public Facilities
a. Manager
b. Security posts
c. Toilet
d. Information center
e. ATM Center 


\section{f. Islamic Prayer Room \\ g. Parking}

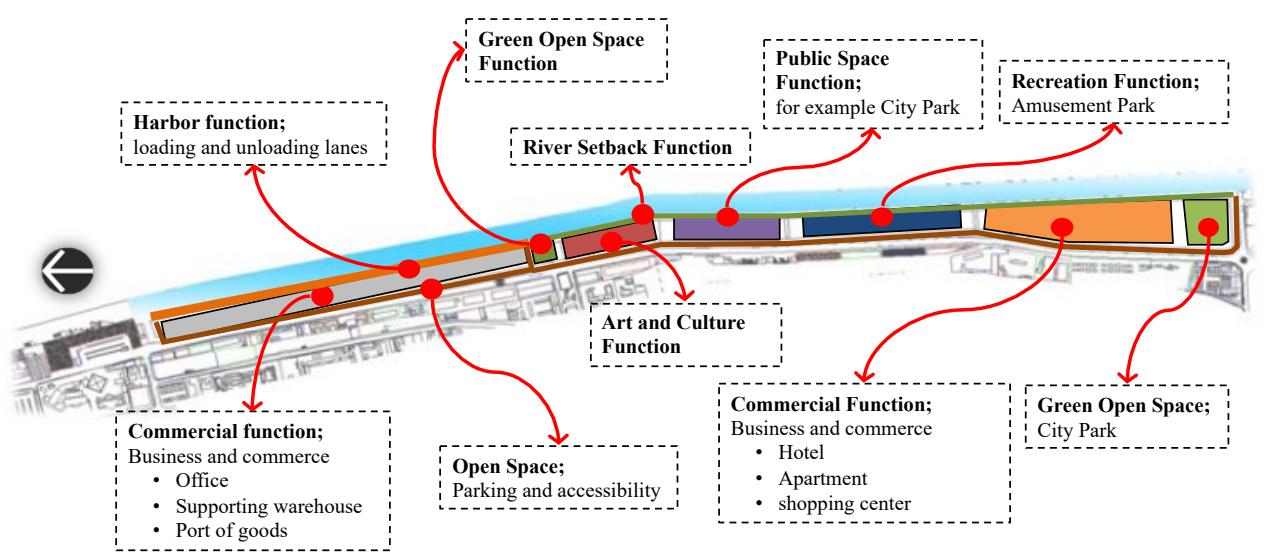

Figure 8. Macro block plan concept

\section{Circulation Concept}

Referring to the fact of the condition of the region as well as the zoning data of the Port of Tanjung Perak area, the circulation concept has alternative choices as follows (Figure 9):

\section{Old Kalimas Port}

a. Heavy Vehicle Circulation

The people's port area has a unique range of circulation, circulation of heavy vehicles such as trucks, containers, cranes, etc. will be maintained as before, with the consideration that the existence of this facility is a complement that is always available or required. But the circulation path will be reorganized, by making a one-way expansion path from the entrance gate of post 3 to post 4 . The selection of this one-way lane is expected to further improve the efficiency of loading and unloading mobility. In this case PT. Pelabuhan Indonesia III (Persero) was given full authority to regulate circulation in Old Kalimas Port area.

b. Unloading Circulation

Unloading, operational and vehicle mobility activities are maintained as before. Like the loading and unloading paths that occur in the area of the river setback with no embankment with the river depth reaching $3 \mathrm{~m}$, and the path with minimum width of $15 \mathrm{~m}$, is still maintained as before, with the proposed elevation of the riverbank by $15 \mathrm{~cm}$ and width of $1 \mathrm{~m}$.

Meanwhile, judging from the loading and unloading activities as well as the facts of the conditions in the field, the existence of an open space area that functions as a stockpiling area. For this reason, the concept begins as follows: there will be 
some open space that will function as a temporary stockpiling area. In this landfill, several facilities to support loading and unloading activities can be included, such as; food stalls / kiosks, places of worship (musholla), security posts, resting places, and public restrooms / bathrooms. To maximize this stockpiling area, it is necessary to have two stockpile areas separated by the circulation path of heavy vehicles (trucks) and flanked by two main warehouses.

2. Tourist, Business and Trade Areas

\section{a. Pedestrian Circulation}

In planning, setting and developing this Kalimas terminal, pedestrian factor is the most important thing. The concept of pedestrian way is still realized, both inside and outside the site. In the site, to avoid boredom (monotonous), the pedestrian way is made winding so as to create a different atmosphere, providing a diverse view for pedestrians to enjoy.

In the arrangement of waterfront areas, which are prioritized for city residents, it is necessary to have special pedestrian paths made along the riverbanks, such as those in waterfront areas abroad. This pathway is called promenade; specifically called because this path is generally very wide, between 10-20 m whose purpose is to accommodate a variety of activities, not only on foot but also daily activities. Activities such as bazaars, sports, picnics, biking, etc., all of which explore to enjoy the river views.

b. Public and Private Vehicle Circulation

Circulation of public vehicles is more concentrated on the west side of the region, the entrance gate and the area's parking area. While the east side is only devoted to pedestrian paths. The proposed parking pattern is a series drive with one-way circulation direction for comfort, safety and efficiency.

c. Commuter Vehicle Circulation

Judging from the physical condition of the area which extends as far as $2.5 \mathrm{~km}$ and is set along the river as a pedestrian path, the choice of public transportation also needs to be considered. Commuter transportation (back and forth) within the area is a required means of transportation. The proposed commuter transportation options include trams or electric trains, electric carts and bicycles. All choices of commuter vehicles should use electric fuel so that the concept of environmentally friendly can also be fulfilled. 


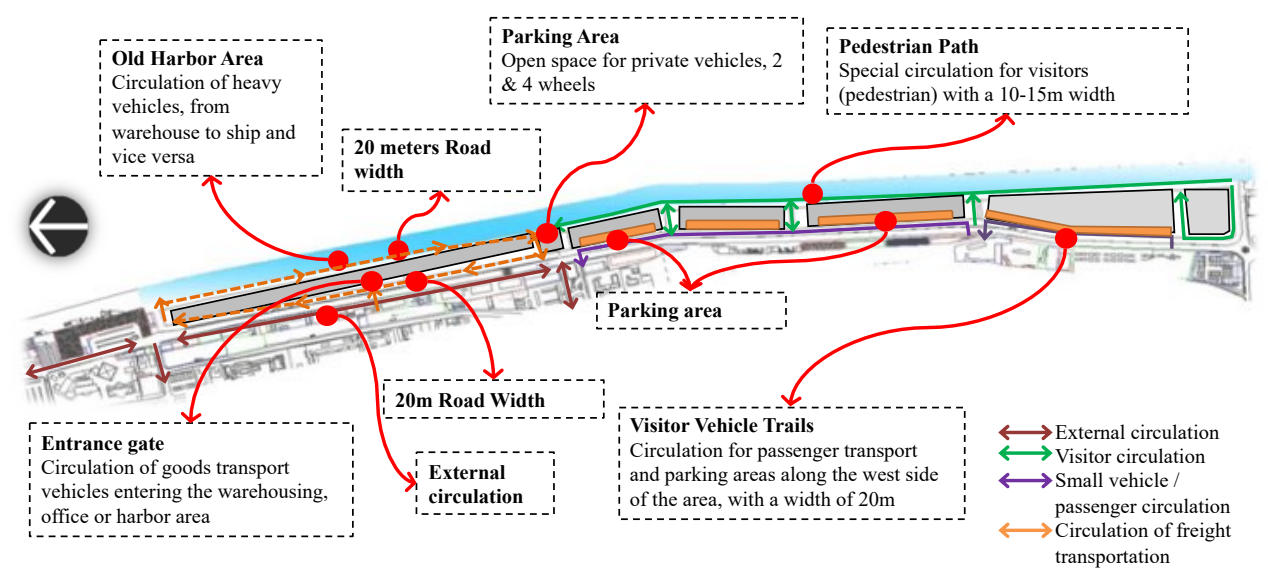

Figure 9. Circulation Concept

\section{The Concept of Building and Environmental Management}

1. Building Construction Concepts

The building is a container that humans need for shelter. But not only that, when the building began to be observed by humans, the symbolic element can become more dominant than just its basic function. This is where the role of architecture begins to run, not only for the element of function but also the element of use.

For building also varies, the proposed use of the building which is expected to function for \pm 24 hours, among others; museums, convention halls, shopping centers (shopping centers), shopping centers and apartments. Judging from the area of land available in the development area and from the physical form of the land that extends, the concept of building arrangement needs to be focused in several points:

a) Side of the north end of the area

Having a small land width and access to the port of the people, then this land is proposed for building a marine museum with consideration of view access, land availability and as a connector for port and maritime activities with city residents.

b) Middle side of the area

Having connectivity with the city area, the central area is more focused on the Convention Hall building, expo arena that can be rented for indoor art performances, music performances and exhibitions. The purpose of the concept of this building is also to give emphasis or a marker of the waterfront region where the center of the gathering of people is a meeting point from every corner of the region.

c) South side of the area 
The south side has the advantage of large land area and view to all corners of the city center. For this reason, the use of buildings as shopping centers and apartments was chosen as an alternative. This building use consideration is based on the Tanjung Perak Port Zoning Area.

In structuring the waterfront area, the water element (river) becomes as important as the soil element which in the context of the building is a function of the road and the surrounding environment. For that the concept of the direction of the building (building orientation) must still prioritize the direction of the water. But in the case of Kalimas, because the building is flanked by a river channel and a public transport line, the building must have at least two building orientations.

2. Environmental Concepts

Open space as part of the Old Kalimas Port planning region has an important role in accommodating 24 hours human activities. This open space must not be deserted or not functioned within 24 hours, so that the concept of bustling (vibrant) by human activity always exists in a waterfront environment. In order be functioned for 24 hours, it is necessary to make a thematic area; which aims to provide a variety of activity options for visitors to the region. The proposed options are commercial and non-commercial recreation areas. The commercial recreation area (amusement park) consists of a variety of rides (attractions) created to attract visitors to interact with these rides in the afternoon-evening. Whereas the proposed non-commercial recreation area consists of various outdoor activities such as flower gardens, picnic parks, children's playgrounds, water playgrounds, tropical rain forest parks and communal areas (shared spaces) for eating and drinking.

\section{E. Utility Network Concepts}

The utility network concept in the development area uses the concept of a ground system, where all drainage facilities, electricity utilities, clean water, telecommunications use underground networks. The utility network in the development area is integrated with a drainage system with a mixed system or a separate system.

\section{CONCLUSIONS}

After case studies and physical analysis of the area, the draft concept of waterfront development began to be prepared. Afterward, the development scenario stage can be formulated, in order to the old Kalimas Port area becomes a successful waterfront area. 
The development of the Tanjung Perak Port is based on the vision and mission of development, which is the waterfront area as a workplace, livable place and play area.

Based on the draft vision and mission concept, the development area will be divided into three major zones, the Old Kalimas Port zone, the recreation zone and the commercial zone. The people's Port zone is more focused on Port adaptability and regional character; the recreation zone is focused on the unification of the Port and the Kalimas riverbanks within the Surabaya; while the commercial zone is focused on providing regional complementary facilities, such as transit shelters (hotels, lodging) and shopping centers.

\section{REFERENCES}

Breen, A., \& Rigby, D. (1996). The new waterfront: A worldwide urban success story. New York: McGraw-Hill.

Breen, A., \& Rigby, D. (Eds.). (1994). waterfronts: cities reclaim their edge. United State: McGraw-Hill,Inc.

Dong, L. (2004). Waterfront development: A case study of Dalian, China. University of Waterloo, Canada.

Goodwin, R. F. (1999). Redeveloping deteriorated urban waterfronts: the effectiveness of U.S. Coastal Management Programs. Coastal Management, 27, 239-269.

Hall, P. (1993) Waterfronts: A New Frontier for Cities in Water; International Centre Cities on Water, Venice, p11.

Hoyle, B. (2002). Urban waterfront revitalization in developing countries: the example of Zanzibar's Stone Town. The Geographical Journal, 168(2), 141-162.

Hussein, H. (2006). Urban recreational riverfronts: Successful revitalisation elements. Journal of Design and the Built Environment, 1(2)

Lynch, K. (1960) The Image of the City; Cambridge (Mass) London: MIT, p42.

Mann, R. (1973) Rivers in the City; David and Charles, Abbot, p13, p16, p20.

National Environment Agency (2011) Singapore River Clean-up: Againts the Odd. Envision, Issue One, a bi-annual NEA Publication. Singapore.

Shirvani, Hamid. (1985), The Urban Design Process, Van Nostrand Reinhold Company, New York.

Torre, L.A. (1989) Waterfront Development; Van Nostrand Reinhold, New York, $\mathrm{p} 4$.

Wrenn, D. M. (1983). Urban Waterfront Development. Washington, D.C: The Urban Land Institute.

Yassin, A. (2010), An evolution of waterfront development in Malaysia. $16^{\text {th }}$ Pacific Rim Real Estate Society Conference, Wellington 24-27 January 2010.

Zhang, L. (2002). An evaluation an urban riverfront park, Riverfront park, Spokane, Washington experience and lessons for designer., Washington State University, United State. 